This is the accepted version of an article published by Brill online in Historical Materialism. Published version available at: http://booksandjournals.brillonline.com/content/journals/10.1163/1569206x-12341520

Accepted version made available from SOAS Research Online: http://eprints.soas.ac.uk/24052/

\title{
Pacifying Urban Insurrections
}

\section{By Laleh Khalili, SOAS University of London, 1k4@soas.ac.uk}

Out of the Mountains: The Coming Age of the Urban Guerrilla, David Kilcullen, London: Hurst \& Co, 2013.

\begin{abstract}
David Kilcullen, an Australian soldier-scholar who acted as counterinsurgency advisor to both the Pentagon and the State Department in the US War on Terror, is refashioning himself as an expert on geospatial security and urban crises. His Out of the Mountains is a Malthusian account of urban disorder in the global South, in what he calls "crowded, complex, and coastal" cities as terrain of future asymmetric warfare. This review situates his work within the intellectual context of counterinsurgency and pacification epistemic community out of which it arises, and addresses why his book may have received plaudits from the socialist urban theorist Mike Davis.
\end{abstract}

Keywords: counterinsurgency, urbanisation, dystopias, coastal cities

In a famous 1965 pamphlet, Lin Biao, a theorist of guerrilla warfare and the Defence Minister of People's Republic of China, promised a tidal surge of rural insurrection "first encircling the cities from the countryside and then capturing the cities." The image of a city besieged by rural guerrillas then also became a synecdoche for global revolution: "Taking the entire globe, if North America and Western Europe can be called 'the cities of the world', then Asia, Africa and Latin America constitute 'the rural areas of the world.' [...] In a sense, the contemporary world revolution also presents a picture of the encirclement of cities by the rural areas." "The speech garnered a great deal of attention at the time, not least from then US Secretary of Defense, Robert McNamara who viewed the speech "as something akin to Hitler's Mein Kampf: a blueprint for the eventual destruction of the United States." "Where the strategists and policy-makers tried to parse the meaning of Lin's speech for the US involvement in Vietnam, at the operational level, military tacticians were moved into action by the enormity of encircled world metropoles, and the horror of waves of rural guerrillas. What the US militarymen considered a nightmarish scenario influenced their counterinsurgency practices for decades, and traces of the thinking about rural counterinsurgencies - developed in the 1960s in Vietnam- remain still in the lineaments of the 2007 version of the US Army Counterinsurgency Field Manual.

This geographic imaginary of cities and countryside - neatly sealed from one another-and operating according to incommensurate logics remained embedded and predominant in US military doctrine. While the 1960s and 1970s were consumed with devising methods of pacification of rural guerrillas primarily in Vietnam, by the 1980s, Military Operations in the Urban Terrain (MOUT) had become a significant mainstay of military research and doctrine in the US, in response to US military and intelligence activities in the Caribbean and the Middle East. If the material necessity of finding ways to consolidate lessons learned from military operations in Grenada, Panama and Beirut counted as one progenitor of US thinking about asymmetric urban warfare, the British operations in Northern Ireland served as an even more important intellectual touchstone. There, the most eloquent proponent of institutionalising lowintensity urban warfare had been General Frank Kitson who had fought in Cyprus, Kenya and Aden, and commanded the British forces in Northern Ireland. Kitson's Low Intensity Conflict, described in the 2007 US Army Counterinsurgency Field Manual as an "explanation of the British

\footnotetext{
${ }^{1}$ Lin Biao 1965.

2 Elliott 2010, p. 141.
} 
school of counterinsurgency from one of its best practitioners" ${ }^{3}$, sought to generalise lessons learned in Belfast to not only urban guerrilla operations in the colonies but also to the thenrestive cities of Europe. In the book, Kitson recounts possible scenarios in which the British military could resort to low-intensity conflict, including in "other potential trouble spots within the United Kingdom." ${ }^{4}$ He writes,

For the future it may well be that social discontent and racial ferment will be more important [than insurgencies], and disturbances arising out of dissatisfaction with society, often allied with racial problems which have not yet been mastered, are already commonplace. ${ }^{5}$

In the US, the idea of urban warfare being used to quell social unrest in cities near and far led to a military officer incanting "Tuzla, Mogadishu, Los Angeles, Beirut, Panama City, Hue, Saigon, Santo Domingo" as "broken cities" that were sites of possible future warfare. ${ }^{6}$ The interconnections between these cities are even clearer in a more recent article by US Army Colonel Robert Killebrew, an irregular warfare specialist, who equates "urban gang warfare and terrorism", Hizbullah and the Crips and the Bloods. Killebrew even writes of "domestic insurgencies" in the article indicating that urban or suburban areas in North America can easily become "ungoverned spaces." The equivalence made between a broad range of contentious and violent actions across a range of continents and political contexts, the militarisation of domestic suppression of local discontent, and the image of cities as distillation of disorder, crime, and insurgency recur again and again in the works of military thinkers tasked with imagining futures that need to be tamed.

Among these military thinkers, David Kilcullen stands apart for his range of scholarly readings and military credentials; and his Out of the Mountains is perhaps the most articulate extended reflection on military operation in urban areas. Kilcullen is an Australian soldier-scholar the field research for whose doctoral thesis was conducted while on military operations in Indonesia. His doctoral thesis shows a confident ability to situate his own military experiences (of peacekeeping in East Timor) and extensive military connections within a set of theoretical or scholarly puzzles. His acknowledgements page also shows the extent to which his research interlocutors were drawn from the military sphere. The work also shows an emerging interest in the geographic differences between urban and rural spaces requiring different military tactics for pacification:

Topographical isolation, poor infrastructure, severe terrain, scattered population groupings and strong influence by traditional hierarchies tend to accelerate and exacerbate the loss of central control [over an area contested by guerrillas]. Conversely good infrastructure, large population centres, good communications and a high degree of influence by nation-state and systemic levels of analysis [?] particularly through economic and governmental institutionalisation- tend to slow such diffusion. ${ }^{8}$

Kilcullen's secondment to the US Department of Defense in 2004 and later assignment to the US Department of State began his meteoric rise in the US military establishment. His initial work concerned counterterrorism strategy and required travel to all the various battlefields of the War on Terror, allowing him to extend his networks of both military men and civilian wonks. The 2006 publication of an article in the Military Review firmly ensconced Kilcullen in the pantheon of

\footnotetext{
${ }^{3}$ US Army 2007, Annotated Bibliography.

${ }^{4}$ Kitson 1971, p. 24. Emphasis added.

${ }^{5}$ Kitson 1971, p. 16.

${ }^{6}$ Peters 1996 quoted in Davis 2006, p. 202.

${ }^{7}$ Killebrew, Robert 2008, p. 12.

${ }^{8}$ Kilcullen 2000, p. vi.
} 
soldier-scholars who had become advocates of counterinsurgency as a tactic to forestall the failure of the flailing US military in Iraq.

Kilcullen's essay, titled “'Twenty-Eight Articles': Fundamentals of Company-level Counterinsurgency" was self-consciously modelled after an essay of similar name written by TE Lawrence in 1917. ' In that earlier article, Lawrence writes not as a counterinsurgent, but as one instigating and inciting an insurgency among Arabs fighting the Ottoman military. Lawrence's "27 Articles" include instructions on how to incorporate a knowledge of the habits and practices of Arabs in the practices of war-fighting, advice about the organisation of war-fighting, and a discussion of how to best manipulate local allegiances and beliefs. Kilcullen's article incorporates some of Lawrence's insistence on local knowledge, and delineates much of the tactical guidelines that were to be later included in the Counterinsurgency Field Manual. 'Twenty-Eight Articles' calls for the accumulation of local knowledge, diffusion of military authority from company commander level down to squad leaders, coordination with other agencies, working with the media, and incorporation of "cultural and political" knowledge. Kilcullen, like Lawrence, is astute enough to recognise the complexities of the context in which military men are to operate. Like Lawrence, Kilcullen looks for malleable social groups that can best act as allies, proxies and nodes of intelligence; for Lawrence these were particular groups of the Bedu; for Kilcullen, they are women. The article has very little to say about geographic specificities of the battlefield. ${ }^{10}$

Kilcullen's next significant contribution to thinking about counterinsurgency was his article in Survival, "Counterinsurgency Redux." 11 This article returns to the notion of "ungoverned spaces" that had been central to his doctoral research and in fact emphasises the difficulty of counterinsurgency in "urban jungles" where "cover and concealment are far greater." ${ }^{2}$ Kilcullen then lays out the complexities of military operations in such an environment - not only are kinetic (or violent) military activities hobbled by the complexity of the urban environment, but so are, crucially, press relations and propaganda by the connectivity characteristic of cities.

Kilcullen has now written the book on urban counterinsurgencies, after two other books that dealt specifically with causes of insurgencies, and strategies and tactics of pacification in the twenty-first century. ${ }^{13}$ His new book, Out of the Mountains, is about contentious and conflictridden coastal cities, and it is exulted not just by the usual suspects -a former UK Security and Intelligence Coordinator, the former Director of Operations and Intelligence at the MI6- but also by Mike Davis, the Marxist scholar of cities, urbanisation, and slums. Out of the Mountains argues that the kinds of threat we face are no longer the ambushes Kilcullen experienced in the mountains of Afghanistan, but emerging urban disorder and unrest. This disorder is caused by "four emerging megatrends of population growth, urbanization, littoralization and networked connectivity" (p. 17). Kilcullen delineates the process through which these trends result in state failure and the breakdown of governance, and the transformation of overcrowded coastal cities into "feral cities" in which crime, terrorism, and local relations of patronage take over. Much of the book is dedicated to analysing the centrifugal forces that operate in these feral cities.

There is not much that is truly original about the book: its discussion of mega-slums borrows a great deal from Planet of Slums. His explanation of the causes of urban disorder is not too dissimilar to that offered by the Modernization Theory of the 1960s, in which revolutions were explained as the regrettable side-effects of incomplete modernization in "traditional" societies. ${ }^{14}$

\footnotetext{
${ }^{9}$ Kilcullen 2006b; Lawrence 1917.

${ }^{10}$ For more on emergence and evolution of counterinsurgency doctrines and practices, see Khalili 2013.

${ }^{11}$ Kilcullen 2006a

12 Kilcullen 2006a, p. 120.

13 Kilcullen 2009; 2010.

${ }^{14}$ The most famous practitioner of such theory was Walt Rostow with his The Stages of Economic Growth: A NonCommunist Manifesto.
} 
The concept of "feral cities" as "security challenges" was itself first coined by a Naval War College scholar, Richard Norton. ${ }^{15}$ Even the focus on littoral cities as targets of networked or distributed counterinsurgency was already well established within military scholarship. ${ }^{16}$

But the book should not be dismissed out of hand, if for no other reason than its defence by Mike Davis, about which more below. But there are other reasons too for taking the book seriously. Kilcullen is certainly one of the most thoughtful and erudite of the generation of soldier-scholars who have so comprehensively moved not only into the spotlight of adoring journalists in the US, but also into the hearts of liberal think-tanks and university departments. ${ }^{17}$ $\mathrm{He}$ is also famous for having declared the invasion of Iraq as "fucking stupid" and going on to argue for ways to extract US out of Iraq (if not Afghanistan). ${ }^{18}$

Out of the Mountains itself cites a number of unexpected scholars: from Saskia Sassen and Stephen Graham (p. 41) to Mike Davis himself (p.290 inter alia), the great scholar of Iraq Hanna Batatu (p. 87), James C Scott (though he is misrepresented, pp. 160-161), and the medieval Muslim sociologist Ibn Khaldun (p. 88). He even quotes Marx and Trotsky, the former on "metabolic" relations between man and nature (though Marx's idea is invoked at second hand and via the concept of "metabolic rift"; p. 41), the latter on how "war is interested in you" even "if you are not interested in war" (p. 24). In his citation of Marx and Trotsky, and a range of Marxist and left scholars, Kilcullen follows a tradition within the metropolitan militaries where "the enemy" is studied (if not always understood) and their work -whether it is the sociological explication of the lives of conquered peoples or military strategies of guerrillas à la Mao or Giap or Guevarabecomes the base texts in opposition to which pacification and counterinsurgency tactics and strategies are shaped.

Kilcullen's book is a carefully written handbook for policymakers and military planners and officers about the control of urban areas in the global South. But there are also moments in which Kilcullen conveys his own experiences vividly, invoking what he was thinking and feeling about urban conflicts. In a telling passage, Kilcullen writes of the sense of dread military men feel about fighting in cities, quoting Mark Bowden's Black Hawk Down: "It seemed like the whole city was shooting at them... Mogadishu was massing in and closing in on them... the city was shredding them block by block...the whole fucking city was trying to kill them!' Kilcullen then goes on to confirm this affective state: "These words resonate with what I ... experienced during the urban counterinsurgency in Iraq: a powerful dread that seems to seep out of the very buildings, roads, and other structures of the urban landscape itself' (p. 74). The displacement of the affective state of soldiers in a war-zone unto the fixed structures of a city, the projection of the subjective feeling of dread unto inanimate objects is characteristic of Kilcullen's representation of cities at war.

Though Kilcullen draws many of his arguments from the work of urban theorists, not all of his generalisations are accurate. In the Middle East and West Africa, the most intense insurgencies are being fought either in predominantly rural hinterlands (as in northern Mali, northern Nigeria, northern Iraq, eastern Syria, or Sinai) or in land-locked cities (like Aleppo, Baghdad, Mosul and Timbuktu); Libya is the notable exception to this trend. Nor would scholars of Jamaica, Liberia, or Latin America agree with the simplistic - not to say moralistic- case studies of urban criminal machines sketched in these pages. In describing the social relations in these cities, Kilcullen recognises the forms of autonomous organisation that occur because of popular ingenuity and collective sentiment, but he only exults those that neatly fit liberal notions of agency and activity (for example, exchange rate markets autonomously established in Mogadishu; p.70).

\footnotetext{
15 Norton 2003.

16 Schmidle 2004.

${ }^{17}$ Kleinfeld 2009; Sewall 2007. On solider-scholars and security wonks see Khalili 2011, p. 1489

18 Kaplan 2013, p. 292.
} 
Kilcullen is at pains not to portray cities at war as stereotypical dens of villainy, but these cities have often already been targets of military or paramilitary police operations, after the completion of which Kilcullen or his "frontier consulting" company employees jet in, sometimes embedded or part of a military, and dispense wisdom about the complex set of relations they are paid to study. This symbiotic relationship between military violence, governmental aid work, and private sector developmental and humanitarian consultancy work has at long been a feature of metropolitan counterinsurgencies, where asymmetric warfare provide the occasions for the remaking of societies, cities, and social relations in the image of capitalist places. ${ }^{19}$

The book sits uncomfortably at the intersection of military doctrine, think-tank memoranda, and academic scholarship. I say uncomfortably because the empirical research contained within its scholarly scaffolding has been gathered not as part of scholarly fieldwork but during military operations or under contract to US and transnational agencies. ${ }^{20}$ Perhaps most striking are the "case studies" Kilcullen includes in the book. These are invariably drawn from the work of his private firm, Caerus. Kilcullen established Caerus in 2010, after having retired from government service. The company is described on its website as "pioneering a new market —one that combines creative tools from industrial and urban design, applied social science, big data analytics, and tech innovations for frontier and conflict environments". ${ }^{21}$ These neo-imperial frontiers -"Afghanistan, Colombia, Egypt, Iraq, Liberia, Libya, Nigeria, Honduras, Somalia, Sri Lanka, and Syria" - are traversed by a range of very obviously capable and intelligent former officials of governmental and transnational aid and development agencies, aided "by local national networks." ${ }^{22}$ These analysts are all attuned to the critiques of orientalism and of militarism, and their aims are good liberal aims of improving the natives by bringing them order and good governance, if not democracy. Indeed, there are moments in the book which work like an extended business brochure for Caerus and for international private development consulting. In the concluding chapter for example, we hear about how Caerus -"we" - "go in on the ground, and we engage directly with the people who live there" (p. 242); and the book offers extended narratives of various Caerus assignments in Honduras, Libya, Liberia, Somalia and Syria, inter alia.

Beyond these criticisms, however, lie two much larger problems. First, that ultimately this book is a military handbook, and even if the explicitly operational material is moved to an appendix (titled "On War in the Urban, Networked, Littoral"), the book's whole point of view, context, and political standpoint are all generated by a military man jocularly comfortable with looking at any sign of disorder as something that can be resolved through military operations (or at least through policies instantiated by powerfully armed and resourced actors). For example, he conflates the "War on Terror" with the "War on Drugs" and any number of other civil wars or domestic "disorders" which the US and its allies have sought to militarily remedy:

Whether the group we're examining is a militia like the Somali National Alliance or Arkan's Tigers, a street gang like the Shower Posse [of Jamaica] or [the Latino] MS13, an organized crime network like the Sicilian Mafia or the Honduran narcos, a soccer club like the Ultras or Red Star Belgrade, a mass movement like Hezbollah, an insurgency like the Taliban, a terrorist group like al Qaeda in Iraq, or a government, the same principles [of competitive control] seem to hold (p. 245).

\footnotetext{
${ }^{19}$ For more on the humanitarian and developmental characteristics of counterinsurgencies see Khalili 2013.

${ }^{20}$ For example he cites "personal observations ... during operations in the destroyed or conflict-affected cities of Nicosia (Cyprus), 1997; Arawa (Bougainville), 1998; Dili (East Timor), 1999-2000; Kabul, Khost, Kandahar, Jalalabad, and Asadabad (Afghanistan), 2006-2012; and Baghdad (Iraq), 2007” (p. 307 fn. 51).

$21<$ http://caerusassociates.com/about/>. Kilcullen has now stepped down from the day to day operations of Caerus.

$22<$ http://caerusassociates.com/services/>
} 
Kilcullen defines the concept of "competitive control" as "the notion that nonstate armed groups, of many kinds, draw their strength and freedom of action primarily from their ability to manipulate and mobilize populations, and that they do this using a spectrum of methods from coercion to persuasion, by creating a normative system that makes people feel safe through the predictability and order that it generates" (p. 114). It is instructive that, originally, the concept of "competitive control" had been used to understand various forms of biological pathologies, or, alternatively, game theoretic solutions for business management problems. But perhaps even more significantly, "competitive control" is precisely the underlying principle of US counterinsurgency practice and theory which Kilcullen and his colleagues have been flogging as far back as 2004. In this reading, counterinsurgency is about competing with the enemy (however defined) for control of the population. As Kilcullen wrote in "28 Articles",

This is the true meaning of the phrase hearts and minds, which comprises two separate components. Hearts means persuading people their best interests are served by your success; minds means convincing them that you can protect them, and that resisting you is pointless. Note that neither concept has anything to do with whether people like you. Calculated self-interest, not emotion, is what counts (p. 136).

The appendix of Out of the Mountains provides a very clear and comprehensive set of guidelines for quelling insurgencies in a densely populated coastal city. Its clear focus on the geospatial planning for the war and the organisational and intelligence needs prior to any invasion certainly shows an attentiveness to the full spectrum of military activities required to succeed in complex urban environments. This form of warfare, Kilcullen argues, necessitates weaning soldiers from "short-duration operations", and entails preparation for long term and gruelling "mobile, improvisational, expeditionary" operations (p. 294). So much, so counterinsurgency.

A far more fundamental problem with the book is its Malthusian understanding of the transformations in the world that lead to conflict. Kilcullen's vision of the overcrowded cities of the world pulsates with a fear, a "dread", of the poor, the brown, the Muslim hordes:

The unprecedented urbanization is concentrated in low-income areas of Asia, Latin America, and Africa... To put it another way, these data show that the world's cities are about to be swamped by a human tide that will force them to absorb -in just one generation - the same population growth that occurred across the entire planet in all of recorded history up to $1960 \ldots$ I should mention that many places affected by rapid urbanization happen to be majority-Muslim, and the takfiri extremists -successors and imitators of Osama bin Laden-will undoubtedly keep threatening their own societies and the world at large (pp. 29$30)$.

Here again, are Lin Biao's developed "cities" of the North besieged by the "rural" insurrection of the global South, but with the added garnish of Islamophobic fear-mongering and hydraulic metaphors. The racialised rhetoric, however, is only one aspect of a Malthusian discourse that blanches at the idea of newcomers to "nature's mighty feast". Malthus had written:

A man who is born into a world already possessed, if he cannot get subsistence from his parents on whom he has a just demand, and if the society do not want his labour, has no claim of right to the smallest portion of food, and, in fact, has no business to be where he is. At nature's mighty feast there is no vacant cover for him. She tells him to be gone, and will quickly execute her own orders, if he does not work upon the compassion of some of her guests. If these guests get up 
and make room for him, other intruders immediately appear demanding the same favour. ${ }^{23}$

So, in a sense, Kilcullen's book is also a manual for keeping the "intruders" -presumably insurrectionary working classes- at the door and in an orderly queue. One may wonder, therefore, why Mike Davis would endorse such a book. The endorsement reads: "This is a brilliant book by the most unfettered and analytically acute mind in the military intelligentsia. Kilcullen unflinchingly confronts the nightmare of endless warfare in the slums of the world".

One could argue that all Davis is doing is accurately describing the hyperventilating hyperbole in Kilcullen's work when he writes of this "nightmare of endless warfare in the slums of the world". But also, presumably, these "slums of the world" are not simply laboratories for militarist fantasies of forces of order, foremost among them US counterinsurgency planners. Whatever criticisms one may have of Davis' own Planet of Slums, his book emphatically does not celebrate this vision of seething urban hordes in need of pacification by military men. ${ }^{24}$ In fact, his book ends with an eloquently resounding warning:

MOUT doctrine ... is thus the highest stage of Orientalism, the culmination of a long history of defining the West by opposition to a hallucinatory Eastern Other. According to [theorist of urban warfare] Stephen Graham, this dichotomizing ideology - now raised to "moral absolutism" by the Bush administration - "works by separating the 'civilised world' - the 'homeland' cities which must be 'defended' - from the 'dark forces,' the 'axis of evil,' and the 'terrorists' nests' of Islamic cities, which are alleged to sustain the 'evildoers' which threaten the health, prosperity, and democracy of the whole of the 'free' world." This delusionary dialectic of securitized versus demonic urban places, in turn, dictates a sinister and unceasing duet: Night after night, hornetlike helicopter gunships stalk enigmatic enemies in the narrow streets of the slum districts, pouring hellfire into shanties or fleeing cars. ${ }^{25}$

Kilcullen's Out of the Mountains is precisely the nightmarish illustration with which The Planet of Slums ends: not only helicopter gunships hovering over enemies in slum alleyways, but also submarine, marine, coastal, riverine and aerial assaults on "an entire coastal strip [which] is one giant urbanized area" (p. 280), as well as "precision bombing" (p. 293), securing "expeditionary energy" (i.e. fuel for military machines) by any means (p. 282), and the ongoing work of "intelligence, surveillance, and reconnaissance" (p. 293). And yet when Tom Hayden writes a review of the book in which he also asks about Davis' blurb, Davis responds thus:

While desperate liberals having been seeking light at the end of Obama's tunnel, Tom has been thunderous in denouncing this scary administration's love affair with executive immunity, special ops and universal surveillance.

But I believe if you carefully read Kilcullen and the literature coming out of places like the Naval War College (where they recently had a think-tank discussing the implications of 'deglobalization'), you'll come to the recognition that the Pentagon's killing machines are not the most profound danger ahead. Rather it's the fact that the military intellectuals are already exploring the consequences of writing off the future of a large part of humanity. They see an absolute darkness on the horizon. ${ }^{26}$

\footnotetext{
23 Malthus 1992[1803], p. 249.

${ }^{24}$ For a criticism of Planet of Slums, see Agnotti 2006.

${ }^{25}$ Davis 2006, pp. 205-206.

${ }^{26}$ Davis 2014.
} 
Davis then goes on to convey a story a US Navy admiral told him about the disaster relief work the US military does:

He emphasized that only the US Navy could bring the infrastructure of a medium-sized city (in the form of ships supplying power, medicine, supplies, helicopters, etc) to a littoral region devastated by floods or quakes. "No one else - not China, Russia, the UK or the UN - has this capability."

"But here's the rub," he said, "Congress will never authorize a serious expansion of humanitarian missions, especially when we're likely to see more Katrinas and Superstorm Sandys on our own coasts." "So at some point," I completed his thought, "no one would ride to the rescue."

What Davis fears then is not Kilcullen's "hearts and minds redux", but an abandoned "surplus humanity" in distress that has been entirely "expell[ed] from the circuits of production" into a "vacuum of ungovernability." 27 Here, Davis takes an insight from Marx but interprets it through the lens of Malthus. In Capital, Marx wrote of the production of a "relative surplus population" as the "reserve army of the unemployed." 28 But this vision of labourers as surplus to the needs of capital reproducing itself is far from the apocalyptic vision of cities in the global South entirely filled with superfluous populations subject to "pandemic disease, famine, and unnatural disaster." ${ }^{29}$ Davis' demographic nightmare ignores the universality of capital today, and the manner in which cities even in the global South, even with vast slums, even on the coasts, actually have their own specific relations of capitalist production, with their own capitalist and managerial and professional classes, with their own organic intellectuals, and with their own specific formation of working class and what Marx called "pauperism".

In the mega-cities of the global South, the capitalists live lives not too dissimilar from those of the bourgeoisie in New York or London. And it might be worth remembering that the lives of working classes -especially if racialised-in littoral and hinterland cities in the US is as cheap if not cheaper than lives in the mega-slums of Mumbai, Lagos, and Rio de Janeiro. In none of these places, do the people Davis describes as an abandoned and forgotten surplus population would want the "protection" of the forces of order, whether they are dressed in the Robocop fineries of the LAPD's SWAT teams and Rio's Polícia Militar, or in the climate-appropriate camouflage of the special operations forces of NATO, or Russia or China for that matter. Even with catastrophic disasters, it is not "humanitarian" militarism that the coastal populations of the Global South need, as Davis well knows. The places where the Pentagon has extended its munificence during manmade and "natural" disasters are the same places that it seeks to expand its sphere of military influence. With the work of the Seabees in the wake of the tsunami in Japan comes the "pivot to Asia". With relief operations after Typhoon Haiyan come expansion of bases in the Philippines Archipelago. With the US Army's Ebola assistance in Liberia comes AFRICOM.

In the end, there are no discernible signs of the US security apparatuses losing interest in the slums of the world, or in military humanitarianism. The US military is ramping up the number of its military "advisors" in Iraq; it conducts a massive bombing campaign in that country and Syria; and is expanding its presence in Africa and East Asia. As to the processes of knowledge production that goes into its military planning, aside from the direct and indirect advisory work of such people as Kilcullen, the Pentagon continues to fund research about the kinds of disorder in the global South that it includes under the heading of national security concerns. One glance at the projects funded by the Pentagon's Minerva programme indicates as much. Minerva funds

\footnotetext{
${ }^{27}$ Davis 2014.

${ }_{28}$ Marx 1887, Chapter 25 Section 3.

${ }^{29}$ Davis 2014.
} 
This is the accepted version of an article published by Brill online in Historical Materialism. Published version available at: http://booksandjournals.brillonline.com/content/journals/10.1163/1569206x-12341520

Accepted version made available from SOAS Research Online: http://eprints.soas.ac.uk/24052/

everything from "Climate Change and African Political Stability" to "A Global Value Chain Analysis of Food Security and Food Staples for Major Energy-Exporting Nations in the Middle East and North Africa"; from "Complex Emergencies and Political Stability in Asia" to "Tackling Critical Mass Outbreaks in Social Contagions" among many other projects about war and domestic disorder. ${ }^{30}$

This imperial fascination with urban disorder all too often is concretised through a combination of military force, humanitarian and developmental processes, and free-market and corporate solutions. If the coming insurrection was once seen to originate in the countryside, the counterinsurgents now envision it as a particularly problematic urban malaise. What happens after the war is the razing of histories, the making of markets and roads, and the transformation of vibrant, chaotic and illegible urban spaces into monitored, surveilled, planned spaces. In Kilcullen and other counterinsurgents' vision for the cities of the global South (and perhaps also the global North), the same roads that facilitate commerce also allow the cavalry through; war founds the market.

It is easy to recognise the emergence of massive coastal cities as a global phenomenon at the conjuncture of urbanisation, industrialisation and deepening interconnections -via the movement of capital and persons and goods, dense webs of transnational maritime, land, and air transport, and the virtual blanket of internet connections and mobile phones and satellite broadcasts. It is, however, important to acknowledge that these cities are not hermetically sealed from a "mythical" rural interior. We know that the human and "natural" ecosystems, economies, social relations, and politics of the cities are far too interwoven with their vast suburbs, exurbs, and rural hinterlands. The megacities of the global South are neither abandoned and forgotten badlands nor heaving hives of unrest threatening to flood the fat and fortified global North. Though both Kilcullen and Davis are right to point out the appalling dearth of public infrastructures and the intensity and extent of urban poverty (which incidentally is as intense and extensive if not more so in rural areas), these cities are also the loci of economic transformation, political mobilisation, and dense and sustaining social relations.

In the conclusion of Planet of Slums, Mike Davis does sound a single ambiguously hopeful note: "the future of human solidarity depends upon the militant refusal of the new urban poor to accept their terminal marginality within global capitalism." ${ }^{31}$ In the years since he wrote those words, the Arab world has seen a revolutionary and counterrevolutionary conflagration which still blazes in large swathes of the region. Citizens in Latin America increasingly demand a right to their cities. New popular movements have emerged in the Atlantic North and Northern Mediterranean, demanding social justice. When I first wrote these words, the flow of traffic on superhighways and the ordinary business of major US cities were being disrupted by activists protesting the racial regime of exploitation and militarised police violence against blacks in that country. The urban poor are not silent, and they demand far more than a place at the table of global capitalism.

\section{References}

Agnotti, Tom 2006, "Apocalyptic anti-urbanism: Mike Davis and his planet of slums", International Journal of Urban and Regional Research 30, 4: 961-967.

Davis, Mike 2006, Planet of Slums, London: Verso.

\footnotetext{
${ }^{30}$ See $<$ http:// minerva.dtic.mil/ funded.html $>$

31 Davis 2006, p. 202.
} 
This is the accepted version of an article published by Brill online in Historical Materialism. Published version available at: http://booksandjournals.brillonline.com/content/journals/10.1163/1569206x-12341520

Accepted version made available from SOAS Research Online: http://eprints.soas.ac.uk/24052/

Davis, Mike 2014, “Comment on Hayden's review”, The Rag Blog (9 July), available at

$<$ http://www.theragblog.com/tom-hayden-books-counterinsurgancy-architect-kilcullen-on-thecoming-age-of-the-urban-guerrilla/\#comment-18490>.

Elliott, Mai 2010, RAND in Southeast Asia: A History of the Vietnam War Era, Santa Barbara, CA: RAND Corp.

Hayden, Tom 2014, “Kilcullen's New Urban Counterinsurgency Plan”, The Rag Blog (8 July), available at $<$ http://www.theragblog.com/tom-hayden-books-counterinsurgancy-architectkilcullen-on-the-coming-age-of-the-urban-guerrilla/>.

Kaplan, Fred 2013, The Insurgents: David Petraeus and the Plot to Change the American Way of War, New York: Simon \& Schuster.

Khalili, Laleh 2011, "Gendered Practices of Counterinsurgency", Review of International Studies 37, 4: 1471-1491.

Khalili, Laleh 2013, Time in the Shadows: Confinement in Counterinsurgencies, Stanford: Stanford University Press.

Kilcullen, David 2000, The Political Consequences of Military Operations in Indonesia 1945-1999, University of New South Wales unpublished doctoral thesis.

Kilcullen, David 2006a, 'Counterinsurgency Redux', Survival 48, 4: 111-130.

Kilcullen, David 2006b, “Twenty-Eight Articles”: Fundamentals of Company-level

Counterinsurgency', Military Review (May-June): 134-139.

Kilcullen, David 2009, The Accidental Guerrilla: Fighting Small Wars in the Midst of a Big One, London: Hurst \& Co.

Kilcullen, David 2010, Counterinsurgency, London: Hurst \& Co.

Killebrew, Robert 2008, 'A New Threat: The Crossover of Urban Gang Warfare and Terrorism', National Strategy Forum Review: 5-23.

Kitson, Frank 1971, Low Intensity Operations: Subversion, Insurgency and Peacekeeping, London: Faber and Faber.

Kleinfeld, Rachel 2009, "Petraeus the Progressive”, Democracy Journal (Winter): 108-115.

Lawrence, TE 1917, 'Twenty-Seven Articles', Arab Bulletin (20 August): 126-133, available at: < http://www.telstudies.org/writings/works/articles_essays/1917_twenty-seven_articles.shtml>

Lin Biao 1965, Long Live the Victory of People's War! available at:

<http://www.marxists.org/reference/archive/lin-biao/1965/09/peoples_war/index.htm>

Norton, Richard 2003, 'Feral Cities', Naval War College Review 56, 4: 97-106.

Malthus, T.R. 1992[1803], An Essay on the Principle of Population, ed. David Winch, Cambridge: Cambridge University Press.

Marx, Karl 1887, Capital: A Critique of Political Economy Vol.1, Samuel Moore and Edward Aveling, edited by Frederick Engels, available at < https://www.marxists.org/archive/marx/works/1867$\mathrm{c} 1 />$.

Peters, Ralph 1996, 'Our Soldiers, Their Cities', Parameters 26, 1: 43-50.

Schmidle Jr., Robert E. 2004, 'Distributed Operations: From The Sea', Marine Corps Gazette 88, 7: $37-43$ 
This is the accepted version of an article published by Brill online in Historical Materialism. Published version available at: http://booksandjournals.brillonline.com/content/journals/10.1163/1569206x-12341520

Accepted version made available from SOAS Research Online: http://eprints.soas.ac.uk/24052/

Sewall, Sarah 2007, “Introduction”, in FM3-24 US Army Counterinsurgency Field Manual, edited by United States Army and Marine Corps, Chicago: University of Chicago Press.

United States Army and Marine Corps, 2007, FM3-24 US Army Counterinsurgency Field Manual, Chicago: University of Chicago Press. 